\title{
DOMINANT HEIGHT PROJECTION MODEL WITH THE ADDITION OF ENVIRONMENTAL VARIABLES
}

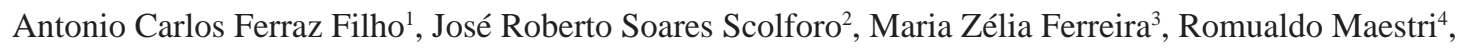 \\ Adriana Leandra de Assis ${ }^{5}$, Antônio Donizette de Oliveira ${ }^{6}$ José Márcio de Mello ${ }^{7}$
}

(received: June 26, 2009; accepted: May 27, 2011)

\begin{abstract}
This study investigated the behavior of climatic variables inserted as inclination modifiers of the Chapman-Richards model for estimating dominant height. Thus, 1507 data pairs from a Continuous Forestry Inventory of clonal eucalyptus stands were used. The stands are located in the States of Espírito Santo and southern Bahia. The climatic variables were inserted in the dominant height model because the model is a key variable in the whole prognosis system. The models were adjusted using 1360 data pairs, where the rest of the data was reserved for model validation. The climatic variables were selected by using the Backward model construction method. The climatic variables indicated by the Backward method and inserted in the model were: mean monthly precipitation and solar radiation. The inclusion of climatic variables in the model resulted in a precision gain of $19.8 \%$ for dominant height projection values when compared with the conventional model. The advantage of the method used in this study is the actualization of inventory data contemplating climatic history and productivity estimates in areas without prior plantation.
\end{abstract}

Key words: Climatic variable, dominant height, projection model.

\section{MODELO DE PROJEÇÃO EM ALTURA DOMINANTE COM ADIÇÃO DE VARIÁVEIS AMBIENTAIS}

RESUMO: Conduziu-se este estudo, com a finalidade de avaliar o efeito da introdução de variáveis ambientais introduzidas como modificadores da inclinação do modelo de Chapman-Richards, para a projeção de altura dominante. Para isso foram utilizados 1507 pares de dados de IFC provenientes de plantios clonais de eucalipto, localizados nos Estados do Espírito Santo e sul da Bahia. As variáveis ambientais foram introduzidas no modelo de altura dominante por ser essa variável chave em todo o sistema de prognose. O ajuste dos modelos foi realizado com 1360 pares de dados, sendo que o restante dos dados foram reservados para a validação do modelo. A escolha das variáveis ambientais foi feita pelo método de construção de modelos Backward. As variáveis ambientais indicadas pelo método Backward e inseridas no modelo de projeção foram: precipitação mensal média e radiação solar média. O ganho com a inclusão das variáveis climáticas na precisão das projeções da altura dominante foi de 19,8\% em relação ao modelo sem variável ambiental. A metodologia de modelagem utilizada neste trabalho apresenta a vantagem de poder atualizar inventários com base no histórico climático e estimar produtividade em locais sem histórico de plantios.

Palavras-chave: Variável climática, altura dominante, modelo de projeção.

\section{INTRODUCTION}

With the development of the Brazilian forest sector and the market's increase in demand for wood products, the application of adequate techniques of forest inventories and management is fundamental to realize a complete and precise diagnosis of forest yield. Thus, the use of such techniques will positively influence planning and decision making, consequently contributing to the success of the enterprise as a whole. To help and simplify the diagnosis of forest yield statistical models are commonly used. Vanclay (1994) defines models as an abstraction, or a simple representation, of some aspect of reality. The author defines a stand growth model as an abstraction of the natural dynamics of a forest stand, and this may encompass growth, mortality, and other changes in stand

\footnotetext{
${ }^{1}$ Forest Engineer, Ph.D. candidate in Forest Science - Departamento de Ciências Florestais - Universidade Federal de Lavras - Cx. P. 3037 - 37200-000 Lavras, MG, Brasil - acferrazfilho@gmail.com

${ }^{2}$ Forest Engineer, Professor Ph.D. in Forest Science - Departamento de Ciências Florestais - Universidade Federal de Lavras - Cx. P. 3037 - $37200-000$ Lavras, MG, Brasil - scolforo@dcf.ufla.br

${ }^{3}$ Forest Engineer, Ph.D. in Forest Science - Veracel Celulose S.A - Cx. P. 23 - 45820-970 - Eunápolis, BA, Brasil - maria.zelia@veracel.com.br ${ }^{4}$ Forest Engineer, Ph.D. in Forest Science - Grandflor - R. João Manoel, 1448 - 97300-970 - São Gabriel, RS, Brasil - rm@grandflor.com.br ${ }^{5}$ Forest Engineer, Ph.D. in Forest Science - Fibria S. A. - Rodovia Aracruz-Barra do Riacho, s/no, Km 25 - 29197-000 - Aracruz, ES, Brasil alassis@fibria.com.br

${ }^{6}$ Forest Engineer, Professor, Ph.D. in Forest Science - Departamento de Ciências Florestais - Universidade Federal de Lavras - Cx. P. 3037 - 37200-000 Lavras, MG, Brasil - donizete@dcf.ufla.br

${ }^{7}$ Forest Engineer, Professor, Ph.D. in Forest Resources - Departamento de Ciências Florestais - Universidade Federal de Lavras - Cx. P. 3037 37200-000 - Lavras, MG, Brasil - josemarcio@dcf.ufla.br
}

Cerne, Lavras, v. 17, n. 3, p. 427-433, jul./set. 2011 
composition and structure. Common usage of the term "growth model" generally refers to a system of equations which can predict the growth and yield of a forest stand under a wide variety of conditions. Thus, a growth model may comprise a series of mathematical equations, the numerical values embedded in those equations, the logic necessary to link these equations in a meaningful way, and the computer code required to implement the model on a computer.

Models can be either mechanistic (process based) or empirical (SCOLFORO, 2006). Mechanistic models attempt to estimate forest growth using edafic, physiological and environmental processes that directly affect growth. Therefore, they are more general models in the sense that they can be applied to estimate the potential productivity in areas without forest and under changing environmental conditions, in other words, they can be used to predict data beyond the observed range used to generate the model. The limitations to apply mechanistic models as a practical tool are due to a large number of parameter values and its complexity.

Due to their simplicity, empirical models are widely used as practical tool by forest managers. These models are calibrated on a forest's permanent plot data (e.g. age, site expressed as height and basal area), capturing consequences and not causes of physiological processes, in this case forest growth. As a result, they are very precise when predicting data in the observed range used to calibrate the model, but tend to be biased when used as a prediction tool outside the observed range.

A hybrid approach combining the main advantages of the process based and empirical models model is being adopted in some circumstances. Snowdon et al. (1998) used climatic indices derived from a mechanistic model, BIOMASS, into an empirical growth model to describe stand height, basal area and volume in a spacing trial with Pinus radiata, improving the fit compared to the basic equation by $13 \%, 22 \%$ and $31 \%$ for mean tree height, stand basal area and stand volume, respectively. Almeida et al. (2002) demonstrated the possibility of integrating the process-based model 3-PG, which estimates forest growth using climatic data and stand characteristics, with the empirical model E-GROW ARCEL, which estimates forest growth recovering parameters of the Weibull probability density function and therefore providing estimates by diameter class. The link between these two models was realized by matching the relation between mean annual increment (3-PG) and site index (E-GROW ARCEL). Growth curves and yields were then successfully generated.
Thus, the objective of this study was to compare the precision of adjustment between a hybrid approach and empirical approach proposed and to model the projection of dominant height values.

\section{MATERIAL AND METHODS}

\subsection{Study area}

The eucalyptus stands studied are located in the States of Espírito Santo and southern Bahia, ranging from latitude $17^{\circ} 15^{\prime} \mathrm{S}$ to $20^{\circ} 15^{\prime} \mathrm{S}$ and longitude $39^{\circ} 05^{\prime} \mathrm{W}$ to $40^{\circ} 20^{\prime} \mathrm{W}$. The stands represent an area of 205 thousand hectares belonging to Fibria S.A. The climate classification of the area, according to Köppen, varies from Aw to Am in Espírito Santo and Af, Am to Aw in Bahia.

\subsection{Data collection}

The data base used came from continuous forest inventory (CFI), realized up to 2005. Each CFI plot had an area of $400 \mathrm{~m}^{2}$ and was installed in the plantation's first year and re-measured yearly until harvest. Of the 1654 data pairs (measurement and re-measurement) 147 were reserved to perform model validation.

Climatic data (precipitation, temperature, solar radiation and vapor pressure deficit) were acquired from a network of 19 automatic weather stations. Seven of the automatic weather stations are located in southern Bahia and the remaining 12 are located in Espírito Santo State. Thiessen's polygon method was used to associate each forest stand to the correct weather station. In this method, the geometric center of each stand is first calculated, and the distances of all the weather stations are calculated from this point. The smallest distance associated the stand to its weather station. The descriptive statistics of the inventory and climatic data is presented in Table 1.

\subsection{Data pairing}

An adequate growth modeling is possible only if a perfect merger between the inventory and climate data is obtained in terms of space and time. In spatial terms, each sample plot had to be correctly associated to the nearest weather station. In temporal terms, first the dates of each inventory measurement and re-measurement were obtained; the mean and coefficient of variation of each climatic variable's monthly mean were then calculated for this period and associated to the inventory data.

\subsection{Selection of the climatic variables}

The climatic variables tested in this study were selected both for their simplicity as for their influence in

Cerne, Lavras, v. 17, n. 3, p. 427-433, jul./set. 2011 
Table 1 - Descriptive statistics of the inventory and climatic data for the model adjustment and validation data base.

Tabela 1 - Estatísticas descritivas dos dados de inventário e climáticos considerando a base de ajuste e validação.

\begin{tabular}{|c|c|c|c|c|c|c|}
\hline \multirow{2}{*}{ Variable } & \multicolumn{3}{|c|}{ Adjustment } & \multicolumn{3}{|c|}{ Validation } \\
\hline & Mean & Min & Max & Mean & Min & Max \\
\hline \multicolumn{7}{|l|}{ Inventory } \\
\hline Initial Age - Ag1 (year) & 3.7 & 1.0 & 7.0 & 3.5 & 1.5 & 5.3 \\
\hline Final Age - Ag2 (year) & 4.7 & 1.9 & 8.0 & 4.5 & 2.4 & 6.3 \\
\hline Dominant height at Ag1 - Dh1 (m) & 18.8 & 4.1 & 29.6 & 18.4 & 9.7 & 26.4 \\
\hline Dominant height at Ag2 - Dh2 (m) & 21.9 & 11.3 & 32.3 & 21.8 & 14.1 & 29.3 \\
\hline Annual Increment in dominant height (m) & 3.2 & 0.0 & 10.1 & 3.4 & 0.0 & 8.6 \\
\hline \multicolumn{7}{|l|}{ Climate } \\
\hline Monthly Precipitation - Prec (mm) & 99.2 & 55.0 & 194.0 & 101.0 & 52.0 & 185.0 \\
\hline Precipitation’s Coefficient of Variation - Prec CV (\%) & 85.6 & 47.5 & 138.1 & 85.5 & 47.5 & 124.7 \\
\hline Temperature - Temp $\left({ }^{\circ} \mathrm{C}\right)$ & 23.7 & 20.8 & 26.1 & 23.8 & 22.4 & 25.8 \\
\hline Temperature’s Coefficient of Variation - Temp CV (\%) & 7.7 & 3.3 & 10.8 & 7.8 & 5.4 & 10.7 \\
\hline Solar Radiation - Rad $\left(\mathrm{MJ}^{*} \mathrm{~m}^{-2 *} \mathrm{day}^{-1}\right)$ & 17.4 & 15.5 & 20.4 & 17.4 & 15.7 & 20.4 \\
\hline Solar Radiation’s Coefficient of Variation - Rad CV (\%) & 19.8 & 11.9 & 25.8 & 19.4 & 14.9 & 25.1 \\
\hline Vapor Pressure Defict - VPD (kPa) & 6.9 & 3.0 & 11.5 & 7.0 & 4.1 & 11.5 \\
\hline VPD’s Coefficient of Variation - VPD CV (\%) & 21.9 & 9.3 & 53.1 & 21.0 & 9.3 & 52.5 \\
\hline
\end{tabular}

the variation of forest growth. The simplicity to obtain these variables comes from the fact that they are collected from automatic weather stations, and require no additional processing. The influence of climatic data in forest growth has been widely proven by many authors, such as Maestri (2003) and Temps (2005). The advantage of using climatic data to update a forest inventory is that these variables can help to minimize the errors that occur because of extreme or irregular weather, such as droughts or cold fronts, for example.

To select the climatic variables that most influenced the increment in dominant height the Backwards model building method was used. This method selects the climatic variables that have the greatest potential to explain variation in dominant height growth. All the climatic variables tested in the model are presented in Table 1. In the Backwards selection method, a full-term model (all variables) is initially adjusted, the next step is to remove the least significant terms (the one with the lowest F statistic) until all the remaining terms are statistically significant (SCOLFORO, 2005).

\subsection{Equations with and without climatic variables}

Dominant height is considered a key variable in forest growth and yield modeling, since this variable influences in all the system's estimates. With the improvement of the dominant height precision, the other variables, fundamental to the growth and yield modeling, also have their estimates improved (SCOLFORO, 2006).

For the dominant height projection model, the algebraic difference approach was used, widely applied in forestry modeling (BARROS et al., 1984; CUNHA NETO et al., 1998; OLIVEIRA et al., 2008; SCOLFORO et al., 1998; THIERSCH et al., 2006a,b). This method was initially proposed by Bailey and Clutter in 1974, and was used to develop anamorphic or polymorphic site curves, invariants in relation to the reference age. This method uses data pairs of consecutives measurements of the variable to be estimated. Model 1 was presented by Scolforo (2006) and has the following structure:

$$
D h 2=A\left(\frac{D h 1}{A}\right)^{\frac{\operatorname{Ln}\left(1-e^{i n c *^{*} A g} 2\right)}{\operatorname{Ln}\left(1-e^{i n c *^{*} A g}\right)}}
$$

where:

Dh1 and Dh2 = Dominant height at ages Ag1 and Ag2, respectively;

Ag1 and Ag2 = initial and final ages of measurement, respectively;

$A$ and incl $=$ model's coefficients related to de asymptote and inclination, respectively.

Cerne, Lavras, v. 17, n. 3, p. 427-433, jul./set. 2011 
Model (1) was used for the adjustment without incorporation of climatic variables, and was used to compare the adequacy of adjustment between model (2). The climatic variables were inserted in the equation's "incl" coefficient, which is responsible for the inclination of the yield curve in the Chapman \& Richards model. This model was presented by Maestri (2003).

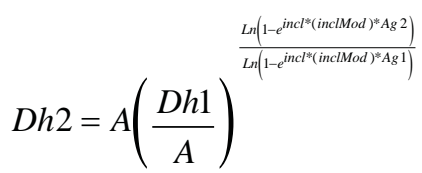

where:

inclMod = Inclination modifier

\section{RESULTS AND DISCUSSION}

\subsection{Adjustment of the equations}

Using the Backward selection method, the climatic variables were selected by adjusting a multiple linear model with the annual dominant height increment as the dependent variable and four climatic variables (precipitation, temperature, radiation and vapor pressure deficit) as the independent variables. Using an $\mathrm{F}$ value of ten to determine which variables to remove from the model, three variables were selected, as can be seen in Table 2 .

Table 2 - Analysis of variance for the three climatic variables selected by the Backwards selection method.

Tabela 2-Análise de variância para as três variáveis climáticas selecionadas pelo método Backwards.

\begin{tabular}{lccccc}
\hline Source & $\begin{array}{c}\text { Sum of } \\
\text { Squares }\end{array}$ & Df & $\begin{array}{c}\text { Mean } \\
\text { Square }\end{array}$ & F-Ratio & P-Value \\
\hline Precipitation & 1421.88 & 1 & 1421.88 & 680.31 & 0.0000 \\
Temperature & 3.37 & 1 & 3.37 & 1.61 & 0.2042 \\
Radiation & 51.08 & 1 & 51.08 & 24.44 & 0.0000 \\
Model & 1476.33 & 3 & 492.11 & 235.45 & 0.0000 \\
Residual & 2834.09 & 1356 & 2.09 & & \\
Total & 4310.42 & 1359 & & & \\
\hline
\end{tabular}

Table 2 shows that of the three variables selected by the Backwards method only temperature was not statistically significant, presenting only a $80 \%$ chance of being able to explain dominant height growth variation. Of all the variables tested, the precipitation was the one that best explained the variance in the annual dominant height increment, according to the F statistic. In order to detect any serious multicollinearity in the model, which is a correlation amongst the predictor variables, a correlation matrix was calculated (Table 3).

Table 3 - Correlation matrix for the model's coefficient estimates.

Tabela 3 - Matriz de correlação entre os coeficientes estimados do modelo.

\begin{tabular}{lcccc}
\hline & Constant & Precipitation & Temperature & Radiation \\
\hline Constant & 1 & -0.3828 & -0.8461 & 0.0103 \\
Precipitation & -0.3828 & 1 & 0.3568 & -0.1850 \\
Temperature & -0.8461 & 0.3568 & 1 & -0.5367 \\
Radiation & 0.0103 & -0.1850 & -0.5367 & 1 \\
\hline
\end{tabular}

A correlation was detected between two of the climatic variables coefficient estimates, radiation and temperature. Therefore, the variable which least contributed to explain the variation in the annual dominant height increment (temperature) was removed from the model. This had the desirable consequence of simplifying the model by removing an extra predictor variable. Hence, the "inclMod" of the equation 2 was determined as presented below (3).

$$
\text { inclMod }=(b 1 * \text { Prec })+(b 2 * \text { Rad })
$$

where:

$b 1$ and $b 2=$ regression coefficients

Prec $=$ Mean monthly precipitation

Rad $=$ Solar radiation

Using the selected climatic variables, the regressions were performed using the different equations and their adequacy of adjustment was analyzed, as shown in Table 4.

An increment in precision was detected in the model considering climatic variables when compared with the model without climatic variables. The climatic model reduced the standard error of estimate from $1.60 \mathrm{~m}$ to $1.26 \mathrm{~m}$, inflicting an improvement of $21.3 \%$ of the estimate's precision. This tendency is also shown in the $\mathrm{R}^{2}$ estimate, which increased from $82.5 \%$ to $88.7 \%$.

\subsection{Validation}

The parameters adjusted in Table 4 were used to project the dominant height values of the validation data base. The model without climatic variables presented an standard error of estimate of $1.67 \mathrm{~m}$, in contrast to the climatic model which presented a value of $1.33 \mathrm{~m}$.

Cerne, Lavras, v. 17, n. 3, p. 427-433, jul./set. 2011 
Table 4 - Adjustment statistics of the dominant height projection models.

Tabela 4 - Estatísticas de ajuste para os modelos de projeção da altura dominante.

\begin{tabular}{|c|c|c|c|c|c|}
\hline \multirow{2}{*}{ Coefficient } & \multicolumn{2}{|c|}{ Parameter estimates } & & \multicolumn{2}{|c|}{ Statistics } \\
\hline & WcV & Climatic model & & Wcv & Climatic model \\
\hline A & 35.503700 & 37.690300 & $\mathrm{R}^{2}$ & $82.48 \%$ & $88.74 \%$ \\
\hline incl & -0.211167 & -0.215177 & SEE & $1.60 \mathrm{~m}$ & $1.26 \mathrm{~m}$ \\
\hline b1 & & 0.015020 & SEE\% & $7.28 \%$ & $5.74 \%$ \\
\hline b2 & & -0.035698 & & & \\
\hline
\end{tabular}

$\mathrm{Wcv}=$ Without climatic variables; SEE = standard error of estimate; SEE\% = standard error of estimate in percentage

Thus, the tendency of precision improvement shown in the adjustment of the models was repeated in the validation process. The model considering climatic variables presented a gain of $19.8 \%$ in the dominant height estimate precision (as determined by the reduction in the standard error of estimate). The precision improvement was also verified in the models' relative residual plots, shown in Figure 1.
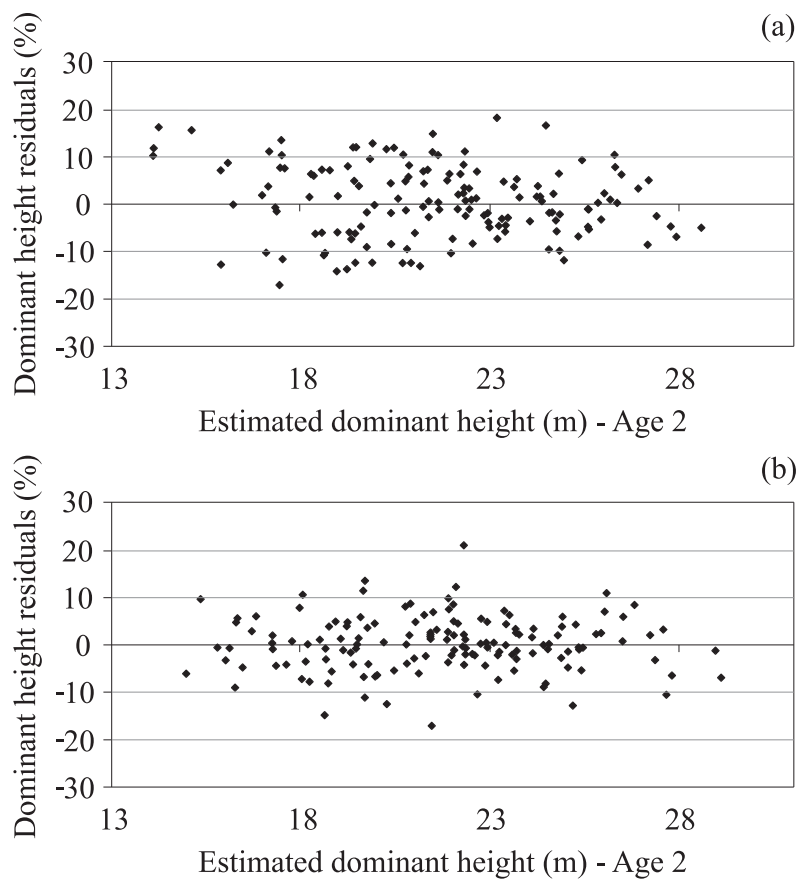

Figure 1 - Dominant height relative residual plots of the models without (a) and with (b) climatic variables using the validation data base.

Figura 1 - Gráficos de resíduos relativos dos modelos de altura dominante sem (a) e com (b) adição de variáveis climáticas utilizando a base de dados de validação.
The residual plot without climatic variables (Figure 1a) showed a greater dispersion of the residuals when compared with the one with climatic variables, especially in the -10 to $10 \%$ of error range of younger dominant height projections (up to 20 meters). In the model with climatic variables (Figure $1 \mathrm{~b}$ ) the residuals tended to be more adherent to the zero value of the x-axis. Although slight, a visual reduction of the residual's dispersion was observed in the model considering climatic variables, thus confirming a greater stability of the adjustment and therefore better dominant height projection values.

\subsection{Model sensibility}

To test sensibility of the model to different climatic values input, a simulation was conducted considering different mean monthly precipitation amounts. All other variables were kept at constant values. The initial input values used were: Ag1 = 2.7; Ag2 = 5; Dh1= 15.4cm; radiation $=17.4 \mathrm{MJ} / \mathrm{m}^{2} /$ day; precipitation $=100 \mathrm{~mm} / \mathrm{month}$. The monthly precipitation values used were correspondent to mean annual precipitation values ranging from 800 to $2300 \mathrm{~mm}$, with $500 \mathrm{~mm}$ amplitude (Figure 2a). As for radiation the values ranged from 15.5 to $21.5 \mathrm{MJ} / \mathrm{m}^{2} /$ day, with $2 \mathrm{MJ} / \mathrm{m}^{2} /$ day amplitude (Figure $2 \mathrm{~b}$ ).

Figure 2a shows that dominant height growth is strongly affected by the precipitation regime in which it is inserted. This confirms the findings of Maestri (2003) and Temps (2005), who also found a strong correlation of dominant height growth and precipitation. At 800mm of mean annual precipitation, the projected value of the dominant height at age 5 years was $20.7 \mathrm{~m}$. In contrast, at $2300 \mathrm{~mm}$ dominant height growth reached $29.1 \mathrm{~m}$, a $40 \%$ difference.

Solar radiation presented an inverse influence on dominant height growth (Figure 2b). The same behavior was found by Maestri (2003). This behavior can be

Cerne, Lavras, v. 17, n. 3, p. 427-433, jul./set. 2011 
(a)
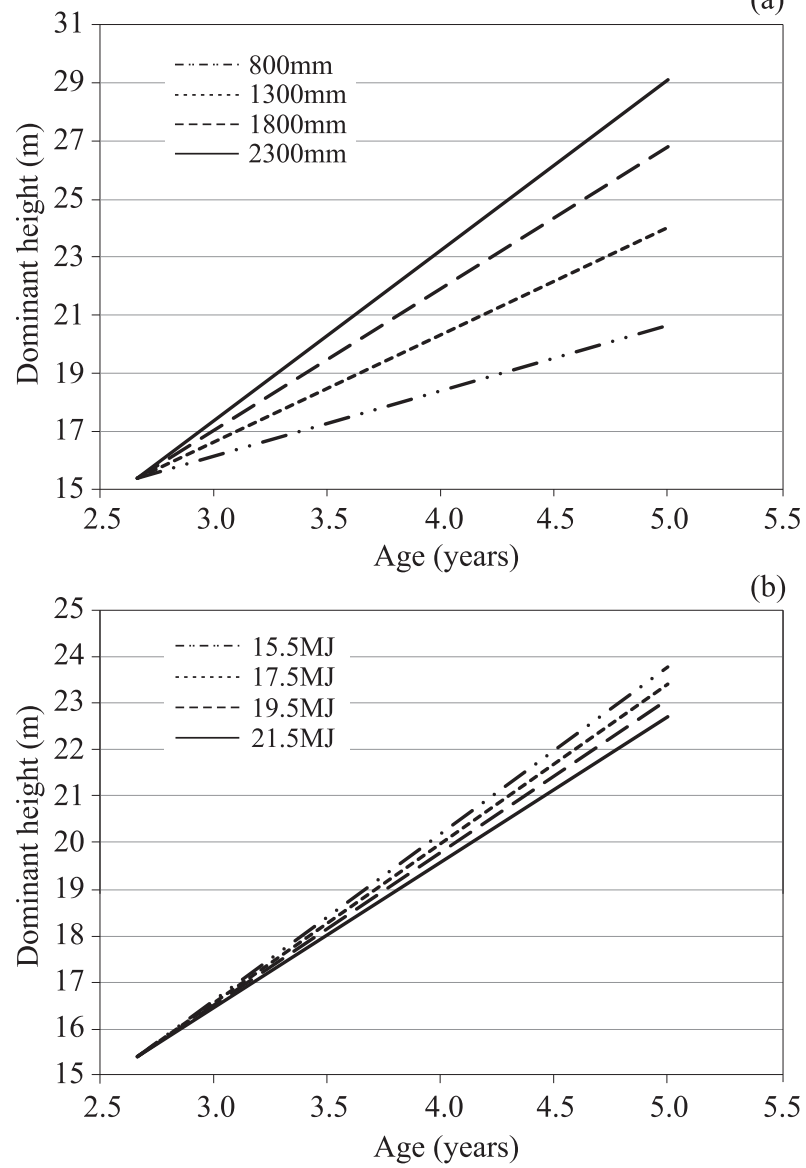

Figure 2 - Dominant height projection estimates considering different mean annual precipitation (a) and solar radiation values (b).

Figura 2 - Estimativas de projeção da altura dominante, considerando diferentes valores de precipitação média anual (a) e radiação solar (b).

attributed to a couple of factors. Firstly, radiation levels tend to be higher on dry seasons (BARRADAS, 1991; BROEK et al., 2001) when forest growth is reduced. Secondly, high incidence of solar radiation raises foliar temperature, which in turn raises foliar transpiration causing the tree to lose water to the environment and consequently grow less (KRAMER \& KOZLOWSKI, 1960). The response of dominant height growth to different levels of solar radiation was weaker than the response to precipitation. At $15.5 \mathrm{MJ} / \mathrm{m}^{2} /$ day of mean daily radiation, the projected value of the dominant height at age 5 years was $23.8 \mathrm{~m}$. In contrast, at $21.5 \mathrm{MJ} / \mathrm{m}^{2} /$ day dominant height growth was reduced to $22.7 \mathrm{~m}$, a $5 \%$ difference.

Cerne, Lavras, v. 17, n. 3, p. 427-433, jul./set. 2011

\section{CONCLUSIONS}

The insertion of climatic variables (precipitation and solar radiation) in the inclination parameter of the Chapman and Richards's model allowed for more precise dominant height projection estimates.

This methodology has its greatest application potential as a forest inventory data updater, in the sense that when past climatic history and stand condition is known, dominant height projection values can account for varying climatic conditions that affect forest growth.

Future projection values are limited by the lack of knowledge of future climatic conditions, however the knowledge of how Eucalyptus height growth varies in relation to mean climatic conditions help predict productivity in areas without prior plantation history.

\section{REFERENCES}

ALMEIDA, A. C.; MAESTRI, R.; LANDSBERG, J. J.; SCOLFORO, J. R. S. Linking process-based and empirical forest models to use as a practical tool for decision-making in fast growing Eucalyptus plantation in Brazil. In: AMARO, A.; TOMÉ, M. (Ed.). Modelling forest systems. Walling Ford: CABI, 2002. p. 63-74.

BARRADAS, V. L. Radiation regime in a tropical dry deciduous forest in western Mexico. Theoretical and Applied Climatology, Amsterdam, v. 44, n. 1, p. 57-64, 1991.

BARROS, N. F.; SILVA, O. M.; PEREIRA, A. R.; BRAGA, J. M.; LUDWIG, A. Análise do crescimento de Eucalyptus saligna em solo de cerrado sob diferentes níveis de N. P. e K. no Vale do Jequitinhonha, MG. IPEF, Piracicaba, n. 26, p. 13-17, 1984.

BROEK, R. van den; VLEESHOUWER, L.; HOOGWIJK, M.; WIJK, A. van; TURKENBURG, W. The energy crop growth model SILVA: description and application to eucalyptus plantations in Nicaragua. Biomass and Bioenergy, New York, v. 21, n. 5, p. 335-349, 2001.

CUNHA NETO, F. R.; SCOLFORO, J. R. S.; OLIVEIRA, A. D.; CALEGARIO, N.; KANEGAE JUNIOR, H. Uso da diferença algébrica para construção de curvas de índice de sítio para Eucalyptus grandis e Eucalyptus urophylla na região de Luiz Antonio, SP. Cerne, Lavras, v. 2, n. 1, p. 2128, 1998. 
KRAMER, P. J.; KOZLOWSKI, T. T. Physiology of trees. New York: McGraw-Hill Book, 1960. 642 p.

MAESTRI, R. Modelo de crescimento e produção para povoamentos clonais de Eucalyptus grandis considerando variáveis ambientais. 2003. 143 p. Tese (Doutorado em Ciências Florestais) - Universidade Federal do Paraná, Curitiba, 2003.

OLIVEIRA, A. D.; FERREIRA, T. C.; SCOLFORO, J. R. S.; MELLO, J. M.; REZENDE, J. L. P. Avaliação econômica de plantios de Eucalyptus grandis para a produção de celulose. Cerne, Lavras, v. 14, n. 1, p. 82-91, 2008.

SCOLFORO, J. R. S. Biometria florestal: modelos de crescimento e produção florestal. Lavras: UFLA/FAEPE, 2006. 393 p. (Textos Acadêmicos).

SCOLFORO, J. R. S. Biometria florestal: parte I, modelos de regressão linear e não-linear, parte II, modelos para relação hipsométrica, volume, afilamento, e peso da matéria seca.

Lavras: UFLA/FAEPE, 2005. 352 p. (Textos Acadêmicos).

SCOLFORO, J. R. S.; RIOS, M. S.; OLIVEIRA, A. D.; MELLO, J. M.; MAESTRI, R. Acuracidade de equações de afilamento para representar o perfil do fuste de Pinus elliotti. Cerne, Lavras, v. 4, n. 1, p. 100-122, 1998.
SNOWDON, P.; WOOLLONS, R. C.; BENSON, M. L. Incorporation of climatic indices into models of growth of Pinus radiata in a spacing experiment. New Forests, Netherlands, v. 16, p. 101-123, 1998.

TEMPS, M. Adição da precipitação pluviométrica na modelagem do crescimento e da produção florestal em povoamentos não desbastados de Pinus taeda L. 2005. 116 p. Dissertação (Mestrado em Ciências Florestais) Universidade Federal do Paraná, Curitiba, 2005.

THIERSCH, C. R.; SCOLFORO, J. R. S.; OLIVEIRA, A. D.; MAESTRI, R.; REZENDE, G. D. S. P. Acurácia dos métodos para estimativa do volume comercial de clones de Eucalyptus sp. Cerne, Lavras, v. 12, n. 2, p. 167-181, 2006a.

THIERSCH, C. R.; SCOLFORO, J. R. S.; OLIVEIRA, A. D.; REZENDE, G. D. S. P.; MAESTRI, R. O uso de modelos matemáticos na estimativa da densidade básica da madeira em plantios de clones de Eucalyptus sp. Cerne, Lavras, v. 12, n. 3 , p. 264-278, 2006b.

VANCLAY, J. K. Modeling forest growth and yield: applications to mixed tropical forest. Wallingford: $\mathrm{CAB}$ International, 1994. $312 \mathrm{p}$.

Cerne, Lavras, v. 17, n. 3, p. 427-433, jul./set. 2011 